\title{
Barriers to compliance \\ with guidelines for health personnel in hospital
}

Berit Evenstad

Smittevernsykepleier

Universitetssykehuset Nord-Norge, Troms $\varnothing$

Lill Sverresdatter Larsen

Sykepleier og førsteamanuensis

Institutt for helse- og omsorgsfag, UiT Norges arktiske universitet, Troms $\varnothing$

Kirsten Gravningen

Overlege

Avdeling for smittevern og beredskap, Folkehelseinstituttet

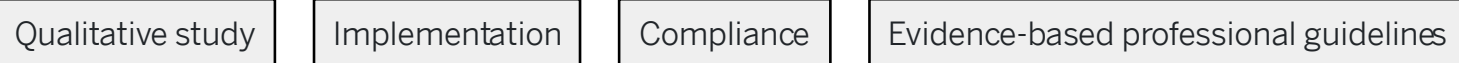

Barriers

Sykepleien Forskning 202015

DOI: 10.4220/Sykepleienf.2020.82573

\section{Summary}

Background: Evidence-based professional guidelines must help to safeguard quality in the health service. Earlier research shows a gap between the guidelines' recommendations and clinical practice. Few studies have examined hospital health personnel's compliance with the guidelines following their implementation. This study is based on the 'Caesarean section project', a project intended to improve quality in a maternity/postnatal unit in which ten new and nine revised guidelines related to the patient care pathway for caesarean sections were introduced in 2014 at the same time as a bundle of interventions. The project was initiated due to the persistent high incidence of surgical site infections following a caesarean section. 
Objective: The study investigates the experiences of clinical health personnel in complying with the professional guidelines three years after the implementation of the caesarean section project.

Method: The study has a qualitative descriptive exploratory research design. A strategic sample of six informants from the maternity/postnatal unit were included in two interdisciplinary focus group interviews, each including a doctor, midwife and paediatric nurse. We analysed the results using Tjora's stepwise deductive-inductive method in addition to Fixsen et al.'s implementation framework.

Results: The informants stated that they found the guidelines difficult to follow if they did not regard them as professionally sound, logical and relevant or in accordance with their own clinical experiences and feelings. Recommendations that competed with the department's professional traditions and values also represented barriers. The informants often explained away non-conformities in relation to the guidelines as an oversight or shortcut. They found it challenging both to give colleagues corrective feedback and to receive feedback when non-conformities were observed, especially in the case of colleagues with a different professional affiliation. When there was doubt about recommended practice, the doctors mainly used the guidelines, while midwives and paediatric nurses often asked a trusted experienced colleague.

Conclusion: The informants' interpretation of guidelines, understanding and handling of non-conformities as well as competing professional traditions and values served as barriers to compliance with the guidelines. The informants wished to be more involved and to have regular active dialogue about guidelines, practical exercises and feedback on their own practice. Studies with a larger sample should be conducted in order to shed more light on the findings of this study.

Evidence-based professional guidelines should quality assure patient treatment, reduce unwanted variations and limit unnecessary or erroneous use of resources in the health service (1). However, research shows that up to 70 per cent of implemented guidelines are not followed (2). Consequently, there may be a gap between professional recommendations and clinical practice.

\section{Earlier research}

The Norwegian Knowledge Centre for the Health Services' summary of international research on the implementation of professional guidelines from 2013 states that some specific measures aimed at health personnel may be effective, but that no measure can guarantee high goal achievement (1). 
In addition to a Norwegian and Canadian review of implementation strategies, this study shows that identifying barriers to the implementation of guidelines and the initiation of specific measures to combat such barriers can promote increased compliance $(1,3,4)$.

It has been shown that a bundle of interventions, entailing the simultaneous implementation of several research-based measures, produces considerably better results than measures that are introduced individually $(5,6)$. Few studies have examined compliance with professional guidelines among clinical health personnel following their implementation $(2,7)$.

\section{Caesarean section project}

The 'Caesarean section project' was an interdisciplinary quality improvement project initiated by management in a maternity/postnatal unit at a university hospital in Norway in October 2013. The project was initiated on account of a high incidence of infection following caesarean sections.

The unit has 1400 births annually, and every fifth delivery is by caesarean section. The unit follows the principles of the 'Baby Friendly standards', which are intended to promote breastfeeding and early mother-baby contact (8).

The goal of the project was to reduce the number of infections in the surgical site following a caesarean section to the national average and to enhance the quality of treatment and patient safety. A comprehensive bundle of interventions consisting of ten new and nine revised guidelines related to the patient care pathway for caesarean sections was devised.

The interventions were introduced to doctors, midwives and paediatric nurses at staff meetings, in three-week daily dropin workshops in the unit, and in internal instruction with practical exercises prior to their adoption on 1 February 2014.

\section{Framework for implementation}

Fixsen et al. describe the implementation of guidelines as a targeted and systematic quality enhancement process (9). Their literature review of studies of service providers in and outside the health service has been instrumental in developing a model for implementation processes, referred to as a framework for implementation (Figure 1) (9). 


\section{Influence}

Organisational structure and culture

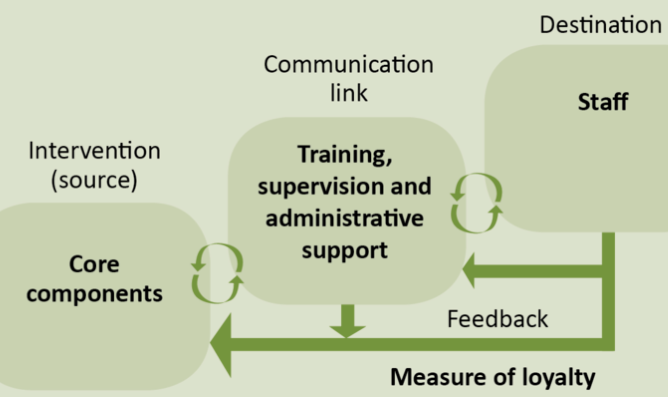

The Intervention (the source) refers to the changes that are to be implemented. The core components are the key content of the intervention. The Destination refers to the staff who are to put the intervention into practice. In the Communication link, training, supervision and administrative support are crucial in quality assuring that staff have the required knowledge, skills and resources to put the changes into practice. Feedback from the staff provides important information about loyalty to the intervention (compliance). Influence refers to the organisational structure and culture that affect all components in the implementation process.

Source: Fixsen DL, Naoom SF, Blase KA, Friedman RM, Wallace F. Implementation research: a synthesis of the literature (9). The figure is based on Roland P.'s translated version in Hva er implementering [What is implementation]. I: Roland P, Westergård E, Eds. Implementering: $\AA ̊ A$ omsette teorier, aktiviteter og strukturer i praksis [Implementation: Converting theories, activities and structures into practice]. Oslo:

The main element in the model is that a set of core components (the intervention) can be implemented among the staff of the organisation (the destination) by means of training, supervision and administrative support (the communication link).

If this implementation is carried out in an appropriate manner, loyalty toward the changes is established and a change in practice may take place (9). Compliance is achieved if the changes introduced are maintained, adapted and further developed (2).

The framework provides a clear understanding of the components of the implementation process, and the article uses it to structure the discussion and evaluate the intervention. Unit management were not using the model when the caesarean section project was planned in autumn 2013 .

\section{The objective of the study}

The objective of the study was to examine the experiences of doctors, midwives and paediatric nurses in complying with the guidelines three years after the end of the 'Caesarean section project', by which time the guidelines had become part of the unit's daily operations. 
The following research question was posed in the study:

How do clinical health personnel perceive barriers to compliance with the professional guidelines three years after the completion of the caesarean section project?

\section{Method}

The study has a qualitative descriptive exploratory research design. We selected a strategic sample of two doctors, two midwives and two paediatric nurses, altogether six informants. All were women with more than ten years' work experience and an average of 13 years' experience in the maternity/postnatal unit.

The inclusion criteria were clinical experience in the use of guidelines before, during and after the implementation of the caesarean section project. Recruitment was via information letters and requests by email, at clinical practice meetings and in informal conversations in the duty room.

\section{Focus group interview}

We used focus groups based on Halkier and Tjora's methods, whereby data are produced in dialogue, discussion and reflection among the participants $(10,11)$. The method is particularly well suited to learning about experiences, attitudes or views in an environment where many people interact (12).

The first author and a secretary conducted two focus group interviews, each including a doctor, midwife and paediatric nurse in December 2016. It is appropriate to have three to four participants when the informants are specialists on the subject $(10,11)$.

Prior to the interviews, we devised a semi-structured interview guide based on discussions between the authors of the article as well as the first author's experiences of pilot testing the interview guide in an in-depth interview. An open introduction was conducive to spontaneous reactions. Thereafter, the discussion turned to the specific topics (11).

The topics were the use of and compliance with the guidelines of the caesarean section project, motivation to comply with the guidelines, professional traditions, and the values of the unit. The questions were open-ended so that informants could exchange experiences related to the topic and comment on each other's views. The questions were also relevant to all the professional groups $(11,13)$. 
Each focus group interview lasted for 90 minutes. We used a

digital audio recorder and transcribed the text verbatim.

\section{Analysis}

We used Tjora's stepwise deductive-inductive method, whereby we worked stepwise from the raw data to reach a conceptual understanding (11). In the first step, we generated empirical data by balancing sample and recruitment, devised an interview guide and conducted focus group interviews.

The second step included transcribing the raw data. In step three - coding - we extracted sentences or groups of sentences that represented the essence of the text extract. Using deductive coding tests we checked whether the codes had been generated from the empirical data rather than beforehand.

The fourth step - code grouping - entailed sorting the codes thematically, while the deductive grouping tests checked whether the code groups were thematically different and had internal consistency. After we had defined the research issue more precisely, we regrouped the code groups into main themes (11) (Table 1). 
Raw data

Midwife 1: In relation to that kind of thing and other experiences I have, I actually feel that midwives are very.... If you feel that the guideline is necessary and important and correct, I find that we're very loyal to them. Yes, that's what I think in fact.

Interviewer: Is it ever the case that you don't follow the guidelines? Paediatric nurse 1: You're supposed to take the blood pressure twice, and then the rectal temperature.

Midwife 1: Yes, people dread that

Paediatric nurse 1: Yes.

Midwife 1: Rectal temperatures, that's not fun at all.

Paediatric nurse 1: No, at least not the first day.

Midwife 1: It's painful lying on your side, and it's uncomfortable

and actually a bit demeaning. So I think many people are slipshod.

Paediatric nurse 1: Yes, I think so too.

Interviewer: But when you say you dread this, is it out of consideration for the patient?

Paediatric nurse 1: Yes, or the patient says they haven't the strength to turn, or...

Midwife 1: No, yes. It's a combination of things, and I think it's a bit difficult for us, I don't know. Sticking the thermometer into the rectum, it's no fun.

Doctor 1: You're kind of down there when you deliver the child [everyone laughs].

Midwife 1: I know, that doesn't affect me at all [laughs].

Doctor 1: But if anyone is focused on that area, it's me of course. Midwife 1: And then there's me [laughs]. Yes, I don't know. But then, when the baby has been delivered, and you have to stick the thermometer into the rectum, it's...

Paediatric nurse 1: It's mostly because the patient is in a lot of pain, I think, or that it's difficult for them to turn.

Midwife 1: And they think it's demeaning

Paediatric nurse 1: And then I think, is this really necessary.

Midwife 1: Yes, do we have to. Yes, so I think maybe we deviate

a bit there, yes.

Paediatric nurse 1: Yes, we deviate a bit.

Midwife 2: I think it's really important that if something new is presented in a proper manner, if you're informed about why this is done and about the background, and have a bit of discussion about it, and maybe you will also feel included and be able to participate in the new things that are happening.

Paediatric nurse 2: Then there were the workshops, I thought they were really good, and I think everyone understood everything. Midwife 2: Yes. Involvement, that means a lot when you start up projects. People can kind of be included and be able to say something about it, and feel almost as if their opinions have been sought.

Midwife 1: I come from a surgical unit, so I think the practice was weird. That was before. Removing the dressing and using the same bedding, it was really highly unnatural. But it was kind of okay because the woman was healthy.
Code

\begin{tabular}{l|l|l} 
Code & Code group & Main theme \\
$\begin{array}{l}\text { 156. If midwives feel } \\
\text { the guideline is nec- } \\
\text { essary, important and } \\
\text { correct, people are } \\
\text { very loyal to them. }\end{array}$ & $\begin{array}{l}\text { Individual } \\
\text { drivers and } \\
\text { inhibiters }\end{array}$ & $\begin{array}{l}\text { Understand- } \\
\text { ing the guide- } \\
\text { lines }\end{array}$ \\
$\begin{array}{l}\text { 166. Many people are } \\
\text { slipshod regarding }\end{array}$ & $\begin{array}{l}\text { Knowledge } \\
\text { in action }\end{array}$ & $\begin{array}{l}\text { Understand- } \\
\text { ing the guide- } \\
\text { lines }\end{array}$
\end{tabular}

blood pressure and rectal temperature. People dread this. Is it necessary, do we have to? Painful, uncomfortable, demeaning. 1 don't think we follow the guidelines.
252. Important that new things are presented in a proper manner that you are told about the justification and the background. Involvement means a lot.
58. Came from surgical practice, thinks practice in the unit was strange and unnatural. But it was kind of okay because the woman was healthy.

In step five, we interpreted the themes in light of Fixsen et al.'s framework for implementation in order to form a conceptual understanding (Figure 1).

\section{Ethical considerations}

The study was approved by unit management and was notified to the Norwegian Centre for Research Data (NSD), which approved the study in August 2016 (project number

49275). 
The informants received information about the objective of the study and the opportunity to withdraw. We obtained voluntary written informed consent beforehand. All the data were handled confidentially, and personally identifiable data were anonymised (14).

\section{Results}

The inductive analysis produced 240 empirical codes dealing with compliance. The codes were thematically sorted into five code groups, then regrouped into three main themes related to barriers to compliance: 1) understanding guidelines, 2) understanding and dealing with non-conformities, and 3) competing professional traditions and values (Table 2).

Table 2. Factors that created barriers to compliance with professional guidelines

\begin{tabular}{|c|c|c|}
\hline Understanding of guidelines & $\begin{array}{l}\text { Understanding and handling } \\
\text { non-conformities }\end{array}$ & $\begin{array}{l}\text { Competing professional traditions } \\
\text { and values }\end{array}$ \\
\hline $\begin{array}{l}\text { Professional guidelines that: } \\
\text { - are not logical or professionally } \\
\text { grounded } \\
\text { - are not relevant to own practice } \\
\text { - are not in accordance with previous } \\
\text { experiences } \\
\text { - conflict with own feelings } \\
\text { - are communicated passively to } \\
\text { health personnel } \\
\text { - are not revised on the basis of the } \\
\text { health personnel's clinical experience }\end{array}$ & $\begin{array}{l}\text { - Non-conformities are described as } \\
\text { oversights and short cuts } \\
\text { - Difficult to give colleagues feedback } \\
\text { and receive feedback from them } \\
\text { when non-conformities are observed } \\
\text { - Asking a colleague about recom- } \\
\text { mended practice instead of following } \\
\text { the guidelines }\end{array}$ & $\begin{array}{l}\text { - Value conflict between regarding } \\
\text { women giving birth as healthy } \\
\text { patients versus surgical patients } \\
\text { - Value conflicts between professional } \\
\text { traditions versus the recommen- } \\
\text { dations of the guidelines }\end{array}$ \\
\hline
\end{tabular}

In the following, we present some of the main findings based on these main themes.

\section{Understanding guidelines}

Doctors, midwives and paediatric nurses were positive to the new guidelines although their understanding varied, and individual experiences and feelings could create barriers to complying with them.

The informants agreed that there had to be professional justification for the guidelines if they were to comply with them. One midwife said: 'When midwives feel that the guideline is necessary, important and correct, I find that we're very loyal to them.'

One doctor described this as follows: 'When it comes to using the guidelines, I think it's important to have information, that you understand the reasoning, that the guidelines are logical and are professionally justified.' 
Some informants thought that general guidelines that did not seem to be specifically related to clinical practice were less relevant to their own practice, which promoted barriers to compliance.

One doctor said as follows: 'The caesarean section project is limited to our patients. It's easier to be motivated for such changes than regulations saying that we must all take off our watches and rings because they might transmit infection to someone or other.'

Previous work experiences could pose a barrier to compliance if they were not in accordance with the guidelines' recommendations. One midwife said: 'You've gained a lot of knowledge and experience over a lifetime in the job, so I'm a bit sceptical even though some people are constantly thrusting one article after the other down your throat.'

\section{三 «The health personnel's feelings could also impact on compliance.»}

The guidelines were perceived as more relevant if they were in accordance with earlier experiences. One paediatric nurse said as follows: 'I found them [the changes in the caesarean section project] excellent. We learned the rules of hygiene, they became automatic.'

The health personnel's feelings could also impact on compliance. One midwife said the following: 'Measuring rectal temperature [twice a day in the first three postoperative days] is no fun. It's painful to lie on your side, it's uncomfortable and actually quite demeaning, so 1 think a lot of us are slipshod as far as that's concerned.'

Professional guidelines that conflict with your own emotions and what you consider to be necessary measures may therefore create barriers to compliance.

All the informants described the challenges of keeping up-todate on changes in the guidelines notified by email, particularly health personnel engaged in shift work and parttime work. The informants suggested regular dialogue and information on guidelines in reports, clinical practice meetings and informal meetings rather than passive email communication. 
One midwife described it as follows: 'If you are informed about the reasons for the guidelines and the background, and there is discussion of the recommendations, you feel involved in the new procedures. Involvement means a lot; you feel as if your opinion is valued.' One paediatric nurse went on to say: 'I think the workshops [in the caesarean section project] were so good that I think everybody took everything on board.'

The guidelines that were not revised on the basis of the health personnel's clinical experience led to differing practices. According to the new guidelines, postoperative wound dressings should be retained and should not be changed until discharge from the hospital.

Midwives and paediatric nurses found that the dressing was not waterproof. It loosened and had to be changed frequently, but the guidelines did not clarify the need to change dressings. Consequently, there were different practices in connection with changing dressings.

\section{Understanding and tackling non-conformities}

All the informants felt that the guidelines in the caesarean section project had been implemented and followed. The informants' descriptions led to a more nuanced understanding of the fact that some guidelines were well implemented while others were only partly implemented.

Deviating from the guidelines was explained away as an oversight or shortcut. In answer to the question on situations in which there was a lack of compliance with the guidelines, one paediatric nurse said: 'You can maybe forget things if it's very busy, if there's a lot of stress or if there's chaos in the ward.' One doctor remarked: 'Forgetting things or taking a shortcut.'

When the informants observed that colleagues failed to follow the guidelines, they found it difficult to speak up. Their decision was influenced by the situation itself and their colleague's professional affiliation. One nurse told us: 'I'm not sure if I would have said anything to you [addressing the doctor] if you had stood there [inspecting the surgical wound] without a mask.' 
The informants also felt it was challenging to receive feedback on their own non-conformities and suggested that they should practice both giving and receiving constructive feedback. The doctor continued: 'It's easier to approach someone and say, "Would you like some help?" or "Shall I give you a face mask?” or "Here you are, here's a face mask for you." Maybe you need to be a bit firm.'

When they were uncertain how to carry out recommended practice, the midwives and paediatric nurses said that they mainly asked experienced colleagues for advice, but used the guidelines if their colleagues were uncertain. One midwife said as follows: 'If I think the answer seems logical, or if it confirms my own suspicions, I can rely on it.'

Doctors mainly used the guidelines to quality assure their own practice because they found that their colleagues gave different answers. One doctor said: 'It depends on who you ask. If we want a definite answer, we must read the guidelines.' Asking colleagues about recommended practice can therefore both strengthen compliance and lead to nonconformities.

\section{Competing professional traditions and values}

The informants described strong professional traditions and values that placed emphasis on women giving birth as healthy patients, and this influenced their professional practice and compliance with the guidelines.

One midwife said the following: 'I came from a surgical department and I found the practice at the maternity/postnatal unit weird [before the caesarean section project]: removing the dressing [first postoperative day] and using the same bedding [postoperative] seemed very unnatural, but it was kind of okay because the woman was healthy.'

\section{$\equiv$ «For some informants, it was difficult to explain the reasons for different practices in seemingly similar situations.»}


For some informants, it was difficult to explain the reasons for different practices in seemingly similar situations. For example, the caesarean section project's guideline on using protective gowns during the daily postoperative change of bedding was largely followed, but transferring principles for the use of protective gowns to similar situations was not a given.

One midwife said the following: 'Yes [we put on protective gowns every time we change bedding post operation], but not [when we change bedding] in the delivery room. I've thought that I don't ... I don't know why.' She added: 'We have received new guidelines saying that we must use a protective gown when we handle the baby. That will meet resistance all the way.'

\section{Discussion}

The informants asserted that the guidelines in the caesarean section project had been implemented and were followed. Meanwhile they described barriers to the guidelines and nonconformities in relation to these. In the discussion, we interpret the results in light of Fixsen et al.'s framework for implementation (9) and their terms 'intervention', 'communication link', 'destination', 'feedback' and 'influence' (Figure 1).

\section{The intervention - insufficient professional justification and relevance}

Based on Fixsen et al.'s implementation model (9), the core components in the intervention were the caesarean section project's new and revised guidelines. How health personnel understood and evaluated the guidelines was important for compliance with them.

A lack of professional justification, or what the informants regarded as illogical reasons, was an obstacle to compliance. The result is in agreement with a qualitative study among nurses at an emergency room in the United States, which describes how clinical recommendations without sufficient professional justification create uncertainty (15).

An Italian account puts forward the argument that doctors' knowledge, attitudes, skills, perceptions, beliefs and values play a critical role as barriers to compliance (16). Wellreasoned, up-to-date and relevant guidelines can help to reduce such barriers. 


\section{«General guidelines were regarded as less relevant than clinical practice guidelines.»}

In our study, general guidelines were regarded as less relevant than clinical practice guidelines. Other studies also show that guidelines perceived by health personnel as relevant to both their own professional practice and the patient population, motivate increased compliance $(2,6)$. This can imply that targeted implementation strategies are more likely to be required for guidelines that are not related to clinical practice.

Midwives and paediatric nurses evaluated the guidelines in light of their own experiences, and experience-based knowledge that was not in line with the recommendations could create barriers to compliance. The result is in keeping with a Norwegian qualitative study among registered nurses (RNs) in hospitals in 2015 , which concludes that RNs rely more on their own experiences and clinical judgement than on research (17).

In evidence-based practice, professional assessments are made on a tripartite division between research-based knowledge, experience-based knowledge and the patient's wishes and needs in a given situation (4). Using their clinical judgment, health personnel must dynamically compare these types of knowledge in different situations (18).

The Norwegian Knowledge Centre for the Health Services' summary of implementation research states that evidencebased practice challenges the standardised practice recommended by professional guidelines (19). Interventions must therefore balance between developing and adapting guidelines for best practice and at the same time acknowledge the importance of clinical judgment (6).

One unexpected finding was the negative reaction of midwives and paediatric nurses to measuring rectal temperature in postoperative women, which is a sensitive method of discovering early signs of infection (20).

Consequently, recommendations that conflict with health personnel's feelings can pose a barrier to compliance with the guidelines. The 2015 Norwegian study found that RNs did not comply with the guidelines if they were unsure whether they benefitted the patient. If indications are unclear, the health personnel should be given a better explanation of the measure. 


\section{The communication link - need for dialogue and participation}

The informants wanted more dialogue on changes in the guidelines as opposed to email communication. Flottorp and Aakhus' 2013 article concludes that passive communication of guidelines has little or no effect on practice, and recommends more active interventions (19).

A Norwegian summary of effective implementation strategies from 2011 recommends that health personnel be more involved in decision-making processes (4). In Fixsen et al.'s implementation model, the communication link is the link between guidelines and clinical health personnel, which is crucial for achieving the necessary knowledge and skills (Figure 1) (9).

We found that staff meetings and workshops for clinical health personnel in a time-limited implementation process were regarded as insufficient to uphold compliance, and that the measures should be a more integral part of the unit's standard practice. Workshops in the unit can strengthen communication (1) and address not only barriers to knowledge but also the attitudes and skills of health personnel (3).

\section{Destination - trade-offs when deciding on a course of action}

In the study, the destination represented the relational processes among clinical health personnel in the maternity/postnatal unit (9). The informants described telling colleagues when they observed non-conformities as challenging. They often explained away non-conformities as an oversight or shortcut rather than acknowledging them as non-conformities.

The Norwegian Knowledge Centre for the Health Services' summary shows that feedback on own practice (audit and feedback) can be effective, especially when given by an experienced colleague or supervisor (1).

Feedback can help to direct attention to compliance and to reveal the need for training and supervision. The communication link should pave the way for the systematic exchange of experience between clinical health personnel. 
In contrast to the doctors, the midwives and paediatric nurses often asked an experienced colleague about nursing issues, and evaluated the answer on the basis of the colleague's experience, the confidence they inspired, and logic. This approach may entail deviating from the guidelines if the colleague is not professionally up-to-date, but can also make a positive contribution to informal professional discussions that can strengthen compliance with the guidelines.

Differing use of the guidelines may require different implementation strategies based on professional affiliation. A study among Canadian nurses shows that the nurses' preferred source of knowledge is colleagues (21). This confirms the need for regular dialogue about guidelines (2).

\section{Feedback - clinical experiences}

Feedback from clinical health personnel can provide important information about loyalty to the changes, i.e. the degree of compliance with the guidelines (9). Feedback can also help to improve and adapt the guidelines, or contribute to measures such as training, supervision and administrative support in the communication link.

The informants' different understandings of how dressing the caesarean section incision should be performed led to dissimilar practices that were in conflict with the guidelines. Feedback is therefore essential to developing the guidelines and ensuring that they are more appropriate, thus reducing the scope for individual interpretation.

Several studies show that continued compliance requires a system in which clinical health personnel can give feedback to those who devise and revise the guidelines $(6,7,22)$. It is vital that several occupational groups are involved in bundles of interventions that require interprofessional collaboration (6).

Guidelines that health personnel have themselves helped to develop can contribute to an increased sense of ownership and may increase compliance by 40 per cent (6). 


\section{Influence - conflict with established practice}

The maternity/postnatal unit's established professional traditions and values competed with the new guidelines and constituted barriers to compliance. According to Fixsen et al's model, the organisational structure and culture affect all components in the implementation process (9).

Implementation strategies should focus more on the impacts that new guidelines may have on the unit's existing practices (15). Clinical health personnel can be made aware of the organisation's professional traditions and values, and how these can affect compliance with the guidelines.

\section{Strengths and limitations}

This study is one of few qualitative studies that examines barriers to compliance with professional guidelines in Norwegian hospitals following the end of a quality improvement project. The group dynamics approach using the focus group interview is a strength.

The study has a small sample of informants from one single maternity/postnatal unit at one hospital. The findings are therefore not necessarily representative of other units and in other settings. Our results may create hypotheses that can be investigated in greater detail in future studies with larger samples and, where relevant, using different methods.

\section{Conclusion}

Professional guidelines that health personnel do not regard as well-reasoned, logical or relevant to their own practice constituted potential barriers to compliance. Barriers could also emerge if the guidelines were not in agreement with their own clinical experiences and feelings or with the unit's professional traditions and values.

The informants wanted to be involved through active dialogue on the guidelines, practical exercises and feedback on their own practice. Studies with a larger sample should be conducted in order to better clarify the findings of the study.

Lill Sverresdatter Larsen is currently president of the Norwegian Nurses Organisation. The article was accepted prior to her appointment as president. 


\section{References}

1. Fretheim A, Flottorp SA, Oxman AD. Effekt av tiltak for implementering av kliniske retningslinjer. Oslo: Nasjonalt kunnskapssenter for helsetjenesten; 2015.

2. Fleiszer AR, Semenic SE, Ritchie JA, Richer MC, Denis JL. A unit-level perspective on the long-term sustainability of a nursing best practice guidelines program: an embedded multiple case study. International Journal of Nursing Studies. 2016;53:204-18.

3. Grimshaw JM, Eccles MP, Lavis JN, Hill SJ, Squires JE. Knowledge translation of research findings. Implementation Science. 2012;7(1):50.

4. Sandvik GK, Stokke K, Nortvedt MW. Hvilke strategier er effektive ved implementering av kunnskapsbasert praksis i sykehus? Sykepleien Forskning. 2011;6(2):160-7. DOI:

10.4220/sykepleienf.2011.0098

5. Resar R, Griffin FA, Haraden C, Nolan TW. Using care bundles to improve health care quality. Cambridge, Massachusetts: Institute for Healthcare Improvement; 2012.

6. Burgansky A, Montalto D, Siddiqui NA. The safe motherhood initiative: the development and implementation of standardized obstetric care bundles in New York. Seminars in Perinatology. 2016;40(2):124-31.

7. Stirman SW, Kimberly J, Cook N, Calloway A, Castro F, Charns M. The sustainability of new programs and innovations: a review of the empirical literature and recommendations for future research. Implementation Science. 2012;7(1):17.

8. Ammehjelpen. «Mor-barn-vennlig standard» og «Ti trinn for vellykket amming» [updated 29.04.2020, cited 21.10.2020]. Available at: https://ammehjelpen.no/morbarnvennlig-initiativ/

9. Fixsen DL, Naoom SF, Blase KA, Friedman RM, Wallace F. Implementation research: a synthesis of the literature. Tampa, Florida: University of South Florida; 2005.

10. Halkier B. Fokusgrupper. Frederiksberg:

Samfundslitteratur, Roskilde Universitetsforlag; 2002. 
11. Tjora AH. Kvalitative forskningsmetoder i praksis. 3 rd ed. Oslo: Gyldendal Akademisk; 2017.

12. Malterud K. Kvalitative metoder i medisinsk forskning forutsetninger, muligheter og begrensninger. Tidsskrift for Den norske legeforening. 2002;122:2468-72.

13. Kvale S, Brinkmann S, Anderssen TM, Rygge J. Det kvalitative forskningsintervju. 3rd ed. Oslo: Gyldendal Akademisk; 2015.

14. De nasjonale forskningsetiske komiteene. Veiledning for forskningsetisk og vitenskapelig vurdering av kvalitative forskningsprosjekt innen medisin og helsefag [updated 23.05.2019, cited 19.05.2020]. Available at: https://www.etikkom.no/forskningsetiskeretningslinjer/Medisin-og-helse/Kvalitativ-forskning/

15. Bourgault AM, Upvall MJ. De-implementation of tradition-based practices in critical care: A qualitative study. International Journal of Nursing Practice. 2019;25(2):e12723.

16. Baiardini I, Braido F, Bonini M, Compalati E, Canonica GW. Why do doctors and patients not follow guidelines? Current Opinion in Allergy and Clinical Immunology. 2009;9(3):228-33.

17. Renolen $\AA$, Hjälmhult E. Nurses experience of using scientific knowledge in clinical practice: a grounded theory study. Scandinavian Journal of Caring Sciences.

2015;29(4):633-41.

18. Nortvedt MW. A arbeide og undervise kunnskapsbasert: en arbeidsbok for sykepleiere. Oslo: Norsk Sykepleierforbund; 2007.

19. Flottorp S, Aakhus E. Implementeringsforskning; vitenskap for forbedring av praksis. Norsk epidemiologi. 2013;23(2):187-96.

20. Edling L, Carlsson R, Magnuson A, Holmberg H. Rektaltermometern fortfarande bäst för temperaturmätning. Klinik och vetenskap. 2009;106(42):2680-3.

21. Estabrooks CA, Chong H, Brigidear K, Profetto-McGrath J. Profiling Canadian nurses' preferred knowledge sources for clinical practice. The Canadian Journal of Nursing Research. 2005;37(2):118-40. 
22. Bahtsevani C, Willman A, Stoltz P, Ostman M.

Experiences of the implementation of clinical practice

guidelines - interviews with nurse managers and nurses in

hospital care. Scandinavian Journal of Caring Sciences.

2010;24(3):514-22. 